\title{
Facile Synthesis of Hollow CuO/MWCNT Composites by Infiltration- Reduction-Oxidation Method as High Performance Lithium-ion Battery Anodes
}

\author{
Gang Zheng, Zhiang Li*, Jinhua Lu, Jinhua Zhang, Long Chen", and Maoping Yang ${ }^{\dagger}$ \\ Gotion High-Tech Co. Ltd. No. 599, Daihe Road, Xinzhan District, Hefei, Anhui, China
}

\begin{abstract}
Hollow copper oxide/multi-walled carbon nanotubes (CuO/MWCNT) composites were fabricated via an optimized infiltration-reduction-oxidation method, which is more facile and easy to control. The crystalline structure and morphology were characterized by X-ray diffraction (XRD), and transmission electron microscopy (TEM). The as-prepared $\mathrm{CuO} /$ MWCNT composites deliver an initial capacity of $612.3 \mathrm{mAh} \cdot \mathrm{g}^{-1}$ and with $80 \%$ capacity retention $\left(488.2 \mathrm{mAh} \cdot \mathrm{g}^{-1}\right)$ after 100 cycles at a current rate of $0.2 \mathrm{~A} \cdot \mathrm{g}^{-1}$. The enhanced electrochemical performance is ascribed to the better electrical conductivity of MWCNT, the hollow structure of $\mathrm{CuO}$ particles, and the flexible structure of the $\mathrm{CuO} / \mathrm{MWCNT}$ composites.
\end{abstract}

Keywords : Copper Oxide (CuO), Multi-Walled Carbon Nanotube (MWCNT), Lithium-Ion Batteries, Anode Material

Received : 14 May 2020, Accepted : 19 July 2020

\section{Introduction}

The ever-growing demand for energy storage system in electric vehicles (EVs), hybrid electrical vehicles (HEVs) and portable electronic devices such as mobile phones, tablets and laptops has accelerated the consumption of lithium ion batteries (LIBs) [1-2]. As the state-of-the-art anode material for most of the commercial lithium ion batteries currently, graphite has several advantages such as low prices, abundant, readily available and non-toxic [3-4]. But the low capacity (theoretical capacity is $372 \mathrm{mAh} \cdot \mathrm{g}^{-1}$ ) hinder its application in extreme high energy density LIBs. Recently, transition metal oxides have attracted much attention for the next generation promising anode materials due to the remarkably high specific capacities [5-10]. Copper oxide $(\mathrm{CuO})$, as one of these transition metal oxides family, its high theoretical capacity $\left(670 \mathrm{mAh} \cdot \mathrm{g}^{-1}\right)$, nontoxic, easily produced and affordable price [11] suggest it a better commer-

This author contributed equally to this work.

*E-mail address: lizhiang@gotion.com.cn

DOI: https://doi.org/10.33961/jecst.2020.01004

This is an open-access article distributed under the terms of the Creative Commons Attribution Non-Commercial License (http://creativecommons.org/licenses/by-nc/4.0) Attribution Non-Commercial License (http://creativecommons.org/licenses/by-nc/4.0)
which permits unrestricted non-commercial use, distribution, and reproduction in any medium, provided the original work is properly cited. cial application in next-generation LIBs.

As known to all, the high theoretical capacity of $\mathrm{CuO}$ bases on the conversion reactions $\mathrm{CuO}+2 \mathrm{Li}^{+}+$ $2 \mathrm{e}^{-} \leftrightarrow \mathrm{Li}_{2} \mathrm{O}+\mathrm{Cu}$. During the transition, the excessive volume change can induce particles pulverization, leading to a rapid deterioration of the reversible capacity [12]. In addition, its poor conductivity leads to the poor rate performance [13]. Nowadays, some methods like preparing nano-sized materials, coating or doping carbon materials to form composite materials, have been put forward to overcome these problems [14-17]. Morphology control is also an effective method to improve the performance of the material. Specific morphologies of $\mathrm{CuO}$ particles such as hollow sphere, nanotube, nanosheet, porous-like have been synthesized in recent year [18-21]. But the synthetic processes of these $\mathrm{CuO}$ particles with different morphologies are considerably complex, difficult to control and scale up. So the synthetic processes need to be further improved before adopted in commercial production.

In this work, we adopted a new method (infiltration-reduction-oxidation method) to synthesize the hollow $\mathrm{CuO}$ combined with multi-walled carbon nanotube (MWCNT). The synthesize processes is more facile and easy to control. The electrochemical 
performances of $\mathrm{CuO} / \mathrm{MWCNT}$ composites were studied. The results show that combining the hollow $\mathrm{CuO}$ and MWCNT can not only enhance the rate capacity of $\mathrm{CuO}$ particles, but also buffer the large volume change during the lithium insertion/extraction process. The $\mathrm{CuO} / \mathrm{MWCNT}$ composites have much better rate cyclability and cycle performance.

\section{Experiments}

The MWCNTs (99.2\%) are purchased from Sanshun Zhongke New Materials Co., Shenzhen, China. The length, diameter and specific surface of MWCNT are 5-12 $\mu \mathrm{m}, 30-50 \mathrm{~nm}$ and $85-110 \mathrm{~m}^{2} \cdot \mathrm{g}^{-1}$, respectively. All other reagents used in the present study are analytical grade and purchased from Sinopharm Chemical Reagent Co., Shanghai, China.

\subsection{The synthesis of $\mathrm{CuO} / \mathrm{MWCNT}$ composites}

The $\mathrm{CuO} / \mathrm{MWCNT}$ composites were synthesized by an optimized infiltration-reduction-oxidation method: $107 \mathrm{mg} \mathrm{CuCl} \cdot 2 \mathrm{H}_{2} \mathrm{O}$ and $60 \mathrm{mg}$ MWCNTs were added into $15 \mathrm{ml}$ deionized water. After $15 \mathrm{~min}$ ultrasonic dispersion, the suspension were heated to $60^{\circ} \mathrm{C}$ under alternately magnetic stirring and ultrasonic dispersion until they became slurry like. Then the slurry were put into a vacuum oven to evaporate the distilled water at $40^{\circ} \mathrm{C}$ for $12 \mathrm{~h}$. Subsequently, the dried sample were grinded to powder. Then the powder was put into a tube furnace and heated to $350^{\circ} \mathrm{C}$ for 2 hours at a rate of $10^{\circ} \mathrm{C} \cdot \mathrm{min}^{-1}$ with an $\mathrm{Ar} / \mathrm{H}_{2}$ atmosphere, followed by a treatment at $350^{\circ} \mathrm{C}$ for 10 hours in air condition. At last, the $\mathrm{CuO} / \mathrm{MWCNT}$ composites were obtained. For comparison, pure $\mathrm{CuO}$ particles were prepared by directly evaporating the $\mathrm{CuCl}_{2} \cdot 2 \mathrm{H}_{2} \mathrm{O}$ solution and experienced a parallel calcination process.

\subsection{Material characterization}

Crystal structure of the products was characterized by X-ray diffraction (XRD, Rigaku SmartLab) with $\mathrm{Cu}$ $\mathrm{K} \alpha$ radiation. Thermogravimetric (TG) analysis of the $\mathrm{CuO} / \mathrm{MWCNT}$ composites was processed by thermal analysis apparatus (TG, STA449C, German Netzsch). The morphology was examined by transmission electron microscope (TEM, JEM-2100, JEOL).

\subsection{Electrochemical measurements}

The electrochemical performance was evaluated using CR2032 coin cells. The working electrode was prepared by casting slurries, consisting of the as-prepared powder, Super P carbon black, and polyvinylidene fluoride (PVDF) in a weight ratio of $8: 1: 1$ and with N-methyl-2-pyrrolidine (NMP) as solvent, on a copper foil. Subsequently, the electrode was dried at $80^{\circ} \mathrm{C}$ for $12 \mathrm{~h}$ in the vacuum oven. The electrode density of the $\mathrm{CuO} / \mathrm{MWCNT}$ is $1.6 \mathrm{~g} \cdot \mathrm{m}^{-2}$. The amount of active materials $(\mathrm{CuO})$ was controlled as the same either in the $\mathrm{CuO} / \mathrm{MWCNT}$ electrode or in the $\mathrm{CuO}$ electrode. The separator was a polypropylene membrane (ND14, Shanghai Energy New Materials Technology Co., China). Lithium metal was used as counter and reference electrode. The electrolyte was $1 \mathrm{M} \mathrm{LiPF}_{6}$ in a mixture of ethylene carbonate (EC) and diethyl carbonate (DEC) (1:1 volume). Galvanostatic charge-discharge experiment was conducted using NEWARE Cell test system in the voltage range of 0.05-3.0 V (vs. $\left.\mathrm{Li}^{+} / \mathrm{Li}\right)$. Cyclic voltammetry was performed on a CHI660D electrochemical workstation (Shanghai Chenhua Co.) at a scan rate of $0.1 \mathrm{mV} \cdot \mathrm{s}^{-1}$. The Electrochemical Impedance Spectroscopy (EIS) were collected by Autolab electrochemical workstation.

\section{Results and Discussion}

\subsection{Crystal structure and morphology of the $\mathrm{CuO} / \mathrm{MWCNT}$ composites}

The phase composition of $\mathrm{CuO}$ and $\mathrm{CuO} / \mathrm{MWCNT}$ composites were examined by XRD, as shown in Fig. 1. The diffraction peaks of pure $\mathrm{CuO}$ sample are consistent with the standard diffraction pattern of $\mathrm{CuO}$ (JCPDS 98-008-7125). The diffraction peaks at $32.61,35.62,38.78,48.99,53.62,58.22,61.65$, $66.34,68.16,72.61$ and 75.21 degree can be indexed to $(110),(11 \overline{1}),(111),(20 \overline{2}),(020),(202),(11 \overline{3})$, $(31 \overline{1}),(220),(311)$ and $(22 \overline{2})$ crystal planes of $\mathrm{CuO}$. After combining with MWCNT, there is a diffraction peak near 26.08 degree that corresponds to the (002) standard diffraction pattern of Carbon (JCPDS-98005-2230). The broadened and weaker peak in the XRD spectrum indicates a nano-scale crystal size of $\mathrm{CuO}$ particles [22]. No peaks related to any other impurities were detected in the XRD pattern. To measure the content of MWCNTs in the $\mathrm{CuO} / \mathrm{MWCNT}$ composites, a TG test in air atmosphere at a heating rate of $10^{\circ} \mathrm{C} \cdot \mathrm{min}^{-1}$ was conducted, as shown in Fig. 2 . At the beginning of 30 to $200^{\circ} \mathrm{C}$, about $0.1 \%$ weight 


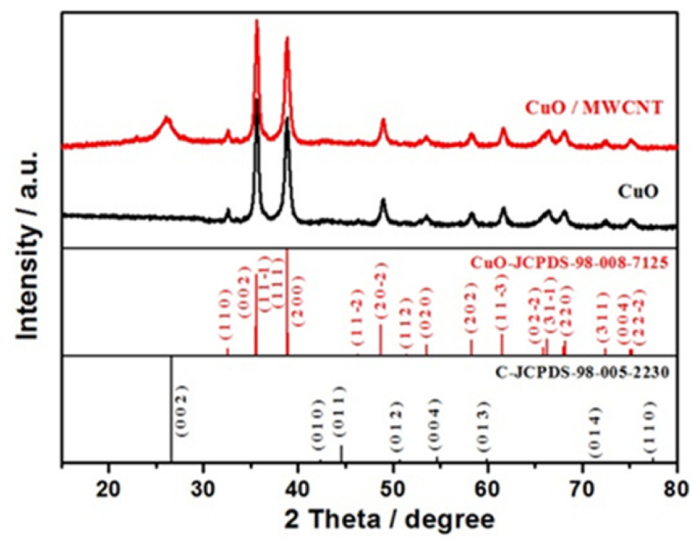

Fig. 1. XRD patterns of pure $\mathrm{CuO}$ and the $\mathrm{CuO} / \mathrm{MWCNT}$ composites.

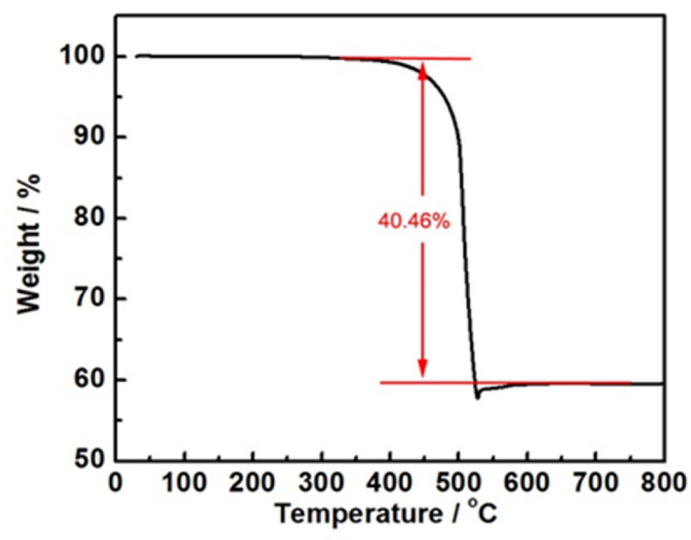

Fig. 2. TG curve of the $\mathrm{CuO} / \mathrm{MWCNT}$ composites in air atmosphere.

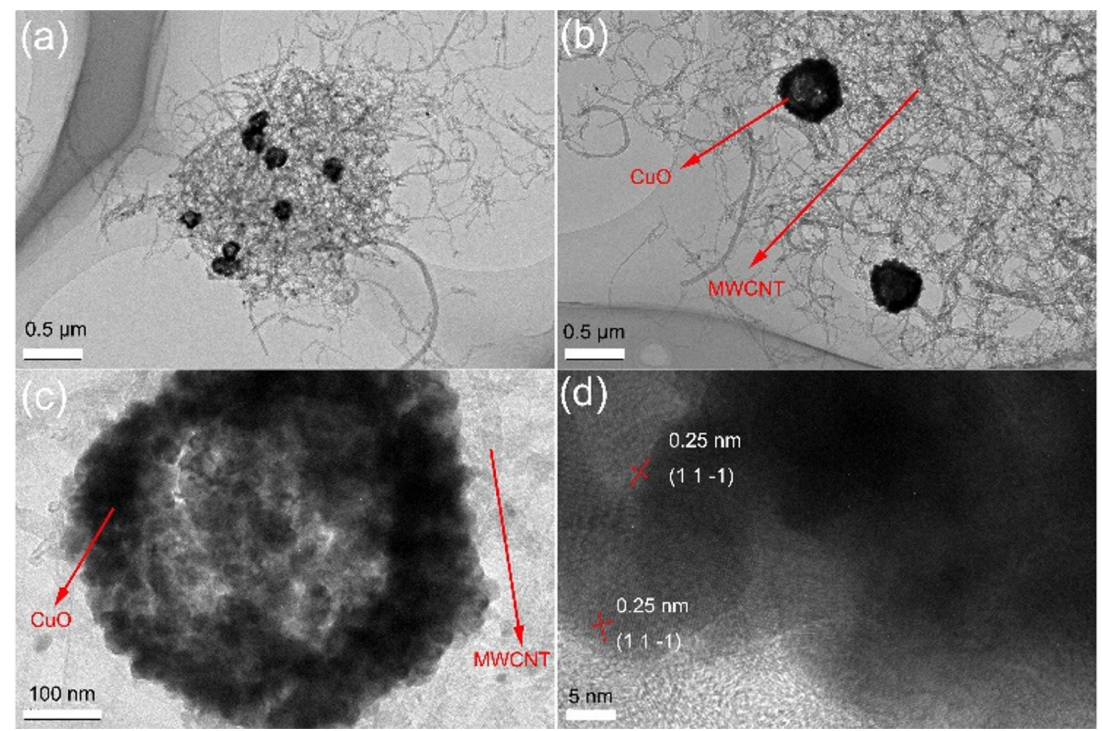

Fig. 3. TEM and HRTEM micrographs of $\mathrm{CuO} / \mathrm{MWCNT}$ composites.

loss was detected. This can be attributed to evaporation of the adsorbed water in the composites. A large weight loss occurs from 320 to $528^{\circ} \mathrm{C}$, corresponding to the oxidation decomposition of carbon nanotubes and the redox reaction between carbon and copper oxide carbon [23]. When the temperature was higher than $528^{\circ} \mathrm{C}$, the weight increment was attributed to the $\mathrm{Cu}_{2} \mathrm{O}$ oxidized to $\mathrm{CuO}$. From 320 to $700^{\circ} \mathrm{C}, 40.46 \%$ weight loss was detected. Therefore, the mass percentage of $\mathrm{CuO}$ in the $\mathrm{CuO} / \mathrm{MWCNT}$ composites is about $59.54 \%$.
The TEM and the high resolution TEM (HRTEM) were performed to confirm the morphology of $\mathrm{CuO} /$ MWCNT composites. As shown in in Fig. 3 (a), the dark black ball like particles with a diameter of 300$500 \mathrm{~nm}$ refer to the $\mathrm{CuO}$ particles. The light gray noodles like agglomeration are the MWCNTs. It also indicates that $\mathrm{CuO}$ particles have deposited on the surface of MWCNTs. Fig. 3(c) is the enlarge TEM image of sample. During the synthesis of $\mathrm{CuO} /$ MWCNT composites, the $\mathrm{CuO}$ first reduced by hydrogen and then oxidized to $\mathrm{CuO}$. Due to the 

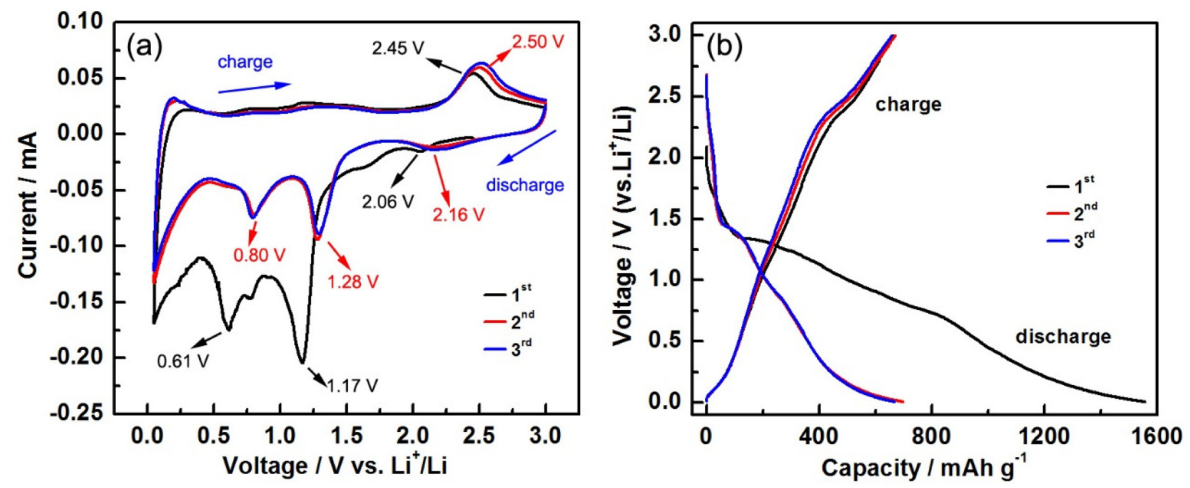

Fig. 4. (a) The first three $\mathrm{CV}$ curves of $\mathrm{CuO} / \mathrm{MWCNT}$ composites in the potential range of $0.01-3.0 \mathrm{~V}$ at a scan rate of 0.1 $\mathrm{mV} \cdot \mathrm{s}^{-1}$; (b) Charge-discharge voltage profiles of the CuO/MWCNT composites at the rate of $0.2 \mathrm{~A} \cdot \mathrm{g}^{-1}$;

Kirkendall Effect [24], the hollow structure of $\mathrm{CuO}$ particles are successfully synthesized. The hollow structure of $\mathrm{CuO}$ particles can be clearly observed. Furthermore, MWCNTs with a diameter of 30-50 nm are binding to the $\mathrm{CuO}$ particles, which indicates a well combination between them. Fig. 3(d) shows the HRTEM images of $\mathrm{CuO}$ particles. The lattice fringe with an interplanar distance of $0.25 \mathrm{~nm}$ refers to the (111) plane of $\mathrm{CuO}$ crystals. The XRD results and TEM images suggest that $\mathrm{CuO} / \mathrm{MWCNT}$ composites with high quality are obtained.

\subsection{Electrochemical performance of the $\mathrm{CuO} /$ MWCNT composites}

The cyclic voltammogram (CV) curves and the galvanostatic charge-discharge curves of the $\mathrm{CuO} /$ MWCNT composites are shown in Fig. 4. In the first discharge process of the $\mathrm{CuO} / \mathrm{MWCNT}$ electrode, as shown in the Fig. 4(a), three cathodic peaks locate at $2.06,1.17$, and $0.61 \mathrm{~V}\left(\mathrm{vs} . \mathrm{Li}^{+} / \mathrm{Li}\right.$ ) can be detected. The weaker broad peak $\sim 2.06 \mathrm{~V}$ corresponds to the solid solution formation of $\mathrm{Li}_{\mathrm{x}} \mathrm{CuO}$ [25]. The prominent peak at $1.17 \mathrm{~V}$ could be ascribed to the formation of intermediate $\mathrm{Cu}_{2} \mathrm{O}$ phase $\left(2 \mathrm{CuO}+2 \mathrm{Li}^{+}+2 \mathrm{e}^{-}\right.$ $\rightarrow \mathrm{Li}_{2} \mathrm{O}+\mathrm{Cu}_{2} \mathrm{O}$ ) and its association with structural destruction as well [26]. Another implicit reduction peak at $0.61 \mathrm{~V}$ corresponds to further reduction of $\mathrm{Cu}_{2} \mathrm{O}$ to purity $\mathrm{Cu}\left(\mathrm{Cu}_{2} \mathrm{O}+2 \mathrm{Li}^{+}+2 \mathrm{e}^{-} \rightarrow \mathrm{Li}_{2} \mathrm{O}+\right.$ $2 \mathrm{Cu}$ ) [26]. During charge process, the peak at $2.45 \mathrm{~V}$ corresponds to the oxidation of $\mathrm{Cu}$ into $\mathrm{Cu}_{2} \mathrm{O}$ and subsequently converted into $\mathrm{CuO}$ as well $\left(\mathrm{Cu}+\mathrm{Li}_{2} \mathrm{O}\right.$ $\left.\rightarrow 2 \mathrm{Li}^{+}+\mathrm{CuO}+2 \mathrm{e}^{-}\right)[25]$. In the second charge and discharge processes, three cathodic peak potentials

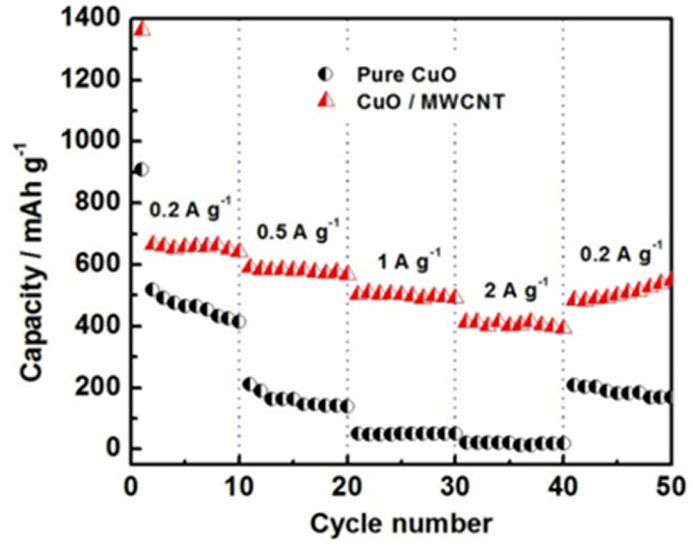

Fig. 5. Rate cyclability of pure $\mathrm{CuO}$ and $\mathrm{CuO} / \mathrm{MWCNT}$ composites at different current densities.

are slightly shifted towards higher voltages (2.16, 1.28 and $0.80 \mathrm{eV}$ ) and the anodic peak potential is shifted to $2.50 \mathrm{eV}$. Fig. 4(b) shows the first three charge-discharge voltage profiles of the $\mathrm{CuO} /$ MWCNT composites at the rate of $0.2 \mathrm{~A} \cdot \mathrm{g}^{-1}$. It indicates that the first discharge curve exhibits a potential plateau at about $1.34 \mathrm{~V}$. In the second discharge process, this potential plateau shifts upward close to $1.46 \mathrm{~V}$ and the curve becomes steeper. The initial discharge-charge capacities of the whole material of the $\mathrm{CuO} / \mathrm{MWCNT}$ composites electrodes are $1555.6 \mathrm{mAh} \cdot \mathrm{g}^{-1}$ and $699.3 \mathrm{mAh} \cdot \mathrm{g}^{-1}$, respectively. The initial coulombic efficiency of $\mathrm{CuO} / \mathrm{MWCNT}$ is $44.9 \%$. The main reason of the low coulombic efficiency at 1 cycle is the side reaction in the battery: the formation of a solidelectrolyte interphase (SEI) layer and the formation 


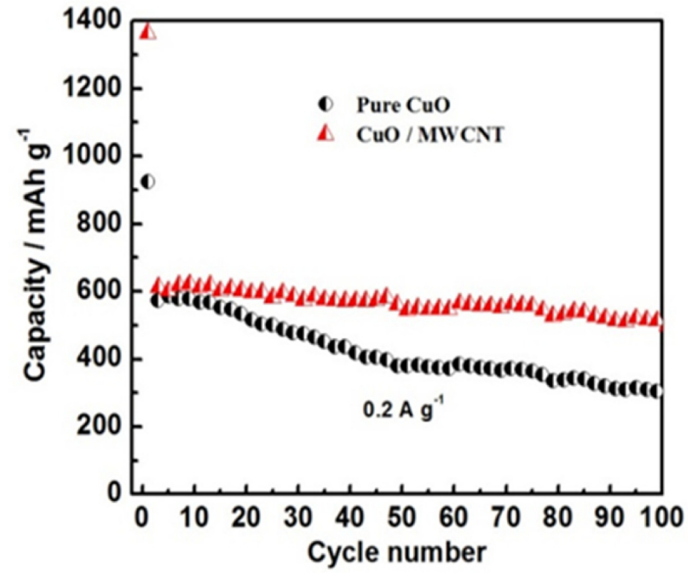

Fig. 6. Cycling performances of pure $\mathrm{CuO}$ and $\mathrm{CuO} /$ MWCNT composites at the current densities of $0.2 \mathrm{~A} \cdot \mathrm{g}^{-1}$.

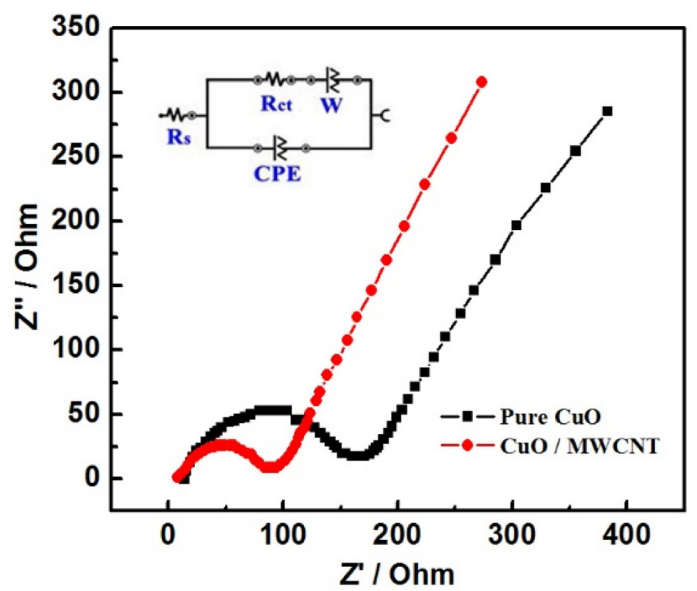

Fig. 7. Nyquist plots of pure $\mathrm{CuO}$ and $\mathrm{CuO} / \mathrm{MWCNT}$ composites. Inset is the equivalent circuits.

Table 1. The performance of oxide anode material.

\begin{tabular}{|c|c|c|c|c|}
\hline The active material & $\begin{array}{l}\text { Initial coulombic } \\
\text { efficiency }\end{array}$ & $\begin{array}{c}\text { Initial discharge capacity } \\
\text { (RT) }\end{array}$ & $\begin{array}{l}\text { Capacity retention ratio } \\
\text { (RT) }\end{array}$ & References \\
\hline $\begin{array}{c}\text { SnOx } \\
\text { (hollow/amorphous) }\end{array}$ & $51 \%$ & $657.2 \mathrm{mAh} \cdot \mathrm{g}^{-1}$ & $\begin{array}{c}81.3 \% \\
\left(400 \text { cycles, } 500 \mathrm{~mA} \cdot \mathrm{g}^{-1}\right)\end{array}$ & [27] \\
\hline $\begin{array}{c}\mathrm{Si} @ \mathrm{SiOx} / \mathrm{C} \\
\text { (Gyroid 3D Network) }\end{array}$ & $80.1 \%$ & $1635 \mathrm{mAh} \cdot \mathrm{g}^{-1}$ & $\begin{array}{c}83.3 \% \\
\left(100 \text { cycles, } 4000 \mathrm{~mA} \cdot \mathrm{g}^{-1}\right)\end{array}$ & [30] \\
\hline HollowCuO@C & $48 \%$ & $660 \mathrm{mAh} \cdot \mathrm{g}^{-1}$ & $\begin{array}{c}92.4 \% \\
\left(200 \text { cycles, } 100 \mathrm{~mA} \cdot \mathrm{g}^{-1}\right)\end{array}$ & [31] \\
\hline $\begin{array}{c}\text { nanosheets } \\
\mathrm{CuO} / \mathrm{MWCNT}\end{array}$ & $59.1 \%$ & $686.9 \mathrm{mAh} \cdot \mathrm{g}^{-1}$ & $\begin{array}{c}78.6 \% \\
\left(50 \text { cycles, } 100 \mathrm{~mA} \cdot \mathrm{g}^{-1}\right)\end{array}$ & [28] \\
\hline $\begin{array}{l}\mathrm{CuO} \text { hollow } \\
\text { nanostructures }\end{array}$ & $63.5 \%$ & $614 \mathrm{mAh} \cdot \mathrm{g}^{-1}$ & $\begin{array}{c}91.4 \% \\
\left(50 \text { cycles, } 150 \mathrm{~mA} \cdot \mathrm{g}^{-1}\right)\end{array}$ & [32] \\
\hline $\begin{array}{c}\text { Hollow } \mathrm{CuO} / \mathrm{MWCNT} \\
\text { (this work) }\end{array}$ & $44.9 \%$ & $699.4 \mathrm{mAh} \cdot \mathrm{g}^{-1}$ & $\begin{array}{c}80 \% \\
\left(100 \text { cycles, } 200 \mathrm{~mA} \cdot \mathrm{g}^{-1}\right)\end{array}$ & \\
\hline
\end{tabular}

of partial irreversible $\mathrm{Li}_{2} \mathrm{O}$ originated from the surface oxide layers [27].

Rate cyclability of pure $\mathrm{CuO}$ and $\mathrm{CuO} / \mathrm{MWCNT}$ composites are shown in Fig. 5. The $\mathrm{CuO} / \mathrm{MWCNT}$ composites can still maintain the discharge capacities of $641.2,568.7,492.2$ and $392.8 \mathrm{mAh} \cdot \mathrm{g}^{-1}$ after 10 cycles at the current density of $0.2,0.5,1$ and $2 \mathrm{~A} \cdot \mathrm{g}^{-1}$, respectively. As a contrast, the rate capacities of pure $\mathrm{CuO}$ are $414.5,138.2,50.9$ and $18.2 \mathrm{mAh} \cdot \mathrm{g}^{-1}$ after 10 cycles at the current density of $0.2,0.5,1$ and $2 \mathrm{~A} \cdot \mathrm{g}^{-1}$, respectively. It is obvious that the $\mathrm{CuO} / \mathrm{MWCNT}$ composites have an excellent rate capacity. Besides, the capacity of $\mathrm{CuO} / \mathrm{MWCNT}$ composites recovered to $550.0 \mathrm{mAh} \cdot \mathrm{g}^{-1}$ at a current density of $0.2 \mathrm{~A} \cdot \mathrm{g}^{-1}$ after different rate cycles, better than that of the pure $\mathrm{CuO}$ whose capacity recovered to $167.3 \mathrm{mAh} \cdot \mathrm{g}^{-1}$. The cycling performances of pure $\mathrm{CuO}$ and $\mathrm{CuO} /$ MWCNT composites are shown in Fig. 6. It is clear that, compared to the pure $\mathrm{CuO}$, the $\mathrm{CuO} / \mathrm{MWCNT}$ composites have a better cycling performance. The initial capacity of the pure $\mathrm{CuO}$ and $\mathrm{CuO} / \mathrm{MWCNT}$ are $572.8 \mathrm{mAh} \cdot \mathrm{g}^{-1}$ and $612.3 \mathrm{mAh} \cdot \mathrm{g}^{-1}$, respectively. The pure $\mathrm{CuO}$ lost nearly half of capacity after 100 cycles at a current density of $0.2 \mathrm{~A} \cdot \mathrm{g}^{-1}$. By contrast, the $\mathrm{CuO} / \mathrm{MWCNT}$ composites have an excellent reversible capacity of $488.2 \mathrm{mAh} \cdot \mathrm{g}^{-1}$ with a capacity retention ratio of $80 \%$, after 100 cycles at a current density of $0.2 \mathrm{~A} \cdot \mathrm{g}^{-1}$. Comparing to the nanosheets 
$\mathrm{CuO} / \mathrm{MWCNT}$ in reference 28 (78.6\% capacity retention after 50 cycles), the $\mathrm{CuO}$ with a hollow structure has a better cycle performance. The detail performance information of oxide anode material are shown in Table 1. According to the Table 1, although the poor initial columbic efficiency is a negative factor of hollow structure oxide materials, they still have a substantial discharge capacity. Moreover, the hollow structure can obviously improve the stability of $\mathrm{CuO} / \mathrm{MWCNT}$ electrode, which is also very important to the commercial production.

The better rate cyclability and cycling performance are attributed to the better electrical conductivity of MWCNTs, the hollow structure of $\mathrm{CuO}$ particles, and the flexible structure of the $\mathrm{CuO} / \mathrm{MWCNT}$ composites. Through combining with MWCNTs, the better electrical conductivity is beneficial to reduce the resistance of the electrode. Fig. 7 is the Nyquist plots of pure $\mathrm{CuO}$ and $\mathrm{CuO} / \mathrm{MWCNT}$ composites analyzed by EIS test. It is observed that the battery with the $\mathrm{CuO} / \mathrm{MWCNT}$ anode has a much smaller AC impedance than that with the pure $\mathrm{CuO}$ anode. The smaller impedance improves the rate cyclability of the anode. Furthermore, the hollow structure of $\mathrm{CuO}$ particles and the flexible structure of the $\mathrm{CuO} /$ MWCNT composites reserves the space for the excessive volume change between the charge and discharge processes [29]. Thus, these special structures could relax the volume expansion, and slow the phenomenon of electrode pulverization and the collapse of the electrode, and then improve the cycling performance of the $\mathrm{CuO} / \mathrm{MWCNT}$ composites.

\section{Conclusions}

The hollow $\mathrm{CuO}$ particles and MWCNT composites have been successfully synthesized through an optimized infiltration-reduction-oxidation method. The $\mathrm{CuO} / \mathrm{MWCNT}$ composites have excellent rate ability capacities and cycle performances. The $\mathrm{CuO} / \mathrm{MWCNT}$ composites have reversible capacity of $488.2 \mathrm{mAh} \cdot \mathrm{g}^{-1}$ after 100 cycles at a current density of $0.2 \mathrm{~A} \cdot \mathrm{g}^{-1}$. This improved synthetic method of the CuO/MWCNT composites is more facile and easy to control, which is more suitable for commercial production.

\section{Acknowledgment}

This work was financially supported by National
Key R\&D Program of China (2016YFB0100304). The authors thanks to the technicians from the Gotion Validation Engineering institute for the support in the XRD and electrochemical characterizations.

\section{References}

[1] M. Li, J. Lu, Z. Chen, and K. Amine, Adv. Mat., 2018, 30 (33), 1800561.

[2] G. Zubi, R. Dufo-López, M. Carvalho, and G. Pasaoglu, Renewable and Sustainable Energy Rev., 2018, 89, 292308.

[3] A. Re. Kamali, and D. J Fray, J. New Mat. for Electrochem. Systems, 2010, 13(2), 147-160.

[4] B. Moradi, and G. G Botte, J. Appl. Electrochem., 2016, 46(2), 123-148.

[5] J. Wu, H. Chen, I. Byrd, S. Lovelace, and C. Jin, ACS Appl. Mat. \& Interfaces, 2016, 8(22), 13946-13956.

[6] Q. Xiong, H. Chi, J. Zhang and J. Tu, J. Alloy Compd., 2016, 688, 729-735.

[7] H. Kim, W. Choi, J. Yoon, J. H. Um, W. Lee, J. Kim, J. Cabana, and W. Yoon, Chem. Rev, 2020.

[8] X. Li, A. Dhanabalan, and C. Wang, J. Power Sources, 2011, 196(22), 9625-9630.

[9] C. Hou, S. Brahma, S. Weng, C. Chang, and J. Huang, J. Electrochem. En. Conv. Stor. 2020, 17(3), 031003.

[10] W. Zhang, L. Feng, H. Chen, and Y. Zhang, Nano, 2019, 14(09), 1950109.

[11] S. Ko, J. Lee, H. S. Yang, S. Park, and U. Jeong, $A d v$. Mat., 2012, 24(32), 4451-4456.

[12] M. Suleiman, M. Mousa, A. Hussein, B. Hammouti, T. B Hadda, and I. Warad, J. Mat. and Environ. Sci., 2013, 4(5), 792-797.

[13] X. Gao, J. Bao, G. Pan, H. Zhu, P. Huang, F. Wu, and D. Song, J. Physical Chem. B, 2004, 108(18), 5547-5551.

[14] B. Wang, X. Wu, C. Shu, Y. Guo, and C. Wang, J. Mat. Chem., 2010, 20(47), 10661-10664.

[15] Z. Yin, Y. Ding, Q. Zheng, and L. Guan, Electrochem. Commun., 2012, 20, 40-43.

[16] C. Wang, D. Higgins, F. Wang, D. Li, R. Liu, G. Xia, N. Li, Q. Li, H. Xu, and G. Wu, Nano Energy, 2014, 9, 334-344.

[17] A. Banerjee, U. Singh, V. Aravindan, M. Srinivasan, and S. Ogale, Nano Energy, 2013, 2(6), 1158-1163.

[18] S. Wang, J. Zhang, and C. Chen, Scripta Materialia, 2007, 57(4), 337-340.

[19] S. Xiao, D. Pan, L. Wang, Z. Zhang, Z. Lyu, W. Dong, X. Chen, D. Zhang, W. Chen, and H. Li, Nanoscale, 2016, 8(46), 19343-19351.

[20] F. Pu, C. Kong, J. Lv, W. Zhang, X. Zhang, S. Yang, H. Jin, and Z. Yang, J. Alloys and Compounds, 2019, 805, 355-362.

[21] S. Jia, Y. Wang, X. Liu, S. Zhao, W. Zhao, Y. Huang, Z. Li, and Z. Lin, Nano Energy, 2019, 59, 229-236.

[22] X. Chen, C. Yu, X. Guo, Q. Bi, M. Sajjad, Y. Ren, X. 
Zhou, and Z. Liu, Nano, 2018, 13(09), 1850103.

[23] Z. Zhu, L. R Radovic, and G. Lu, Carbon, 2000, 38(3), 451-464.

[24] Y. Yin, R. M Rioux, C. K Erdonmez, S. Hughes, G. A Somorjai, and A P. Alivisatos, Science, 2004, 304(5671), 711-714.

[25] A. Debart, L. Dupont, P. Poizot, J. Leriche, and J. Tarascon, J. Electrochem. Soc., 2001, 148(11), A1266.

[26] H. Yin, X. Yu, Q. Li, M. Cao, W. Zhang, H. Zhao, and M. Zhu, J. Alloys and Compounds, 2017, 706, 97-102.

[27] X. Zhao, W. Wang, Z. Hou, Y. Yu, Q. Di, X. Wu, G. Wei, Z. Quan, and J. Zhang, Inorganic Chemistry
Frontiers, 2019, 6(2), 473-476

[28] W. Yuan, Z. Qiu, Y. Chen, B. Zhao, M. Liu, and Y. Tang, Electrochim. Acta, 2018, 267, 150-160.

[29] J. Xiang, J. Tu, J. Zhang, J. Zhong, D. Zhang, and J. Cheng, Electrochem. Commun., 2010, 12(8), 1103-1107.

[30] J. Lee, J. Moon, S. A Han, J. Kim, V. Malgras, Y.-U. Heo, H. Kim, S.-M. Lee, H. K. Liu, and S. X. Dou, ACS nano, 2019, 13(8), 9607-9619.

[31] Y. Dong, X. Jiang, J. Mo, Y. Zhou, and J. Zhou, Chem. Eng. J., 2020, 381, 122614.

[32] J. C. Park, J. Kim, H. Kwon, and H. Song, Adv. Mat., 2009, 21(7), 803-807. 